\title{
Morphometric Investigations on the Horns of Uda Rams in Nigeria: Implications in Veterinary Clinical Practice
}

\author{
Investigaciones Morfométricas de los Cuernos de los Carneros Uda en Nigeria: \\ Implicancias en la Práctica Clínica Veterinaria
}

Olukole, S. G.

OLUKOLE, S. G. Morphometric investigations on the horns of Uda rams in Nigeria: implications in veterinary clinical practice. Int. J. Morphol., 28(2):533-536, 2010.

SUMMARY: Morphometric studies were carried out on the horns of 60 Uda rams. The mean values for the relative horn weight, weights of the right and left horns were $0.67 \%, 219.5 \mathrm{~g}$ and $208 \mathrm{~g}$ respectively. The mean values for the lengths of the right and left horns and the horn base circumference were $25.6 \mathrm{~cm}, 27.4 \mathrm{~cm}$ and $17.4 \mathrm{~cm}$ respectively. There were significant differences $(\mathrm{p}<0.05)$ between the lengths of the right and left horns; and between the weights of the right and left horns. There were also strong positive correlations between the body weight of the animals and the length of the horns. A graph of the length of the right horn against the body weight of the animals with a significant deviation from zero at $95 \%$ confidence intervals yielded a slope value of 0.4535 , being an index that can be used to estimate the approximate body weight of a ram once the length of the right horn is known. This index, the first of its kind in literature, is therefore named the body weight-horn length (BWHL) index. The results obtained in this study will serve as valuable tools in weight estimation in animal management and drug administration in Veterinary clinical practice. It also provides a baseline data on the horns of Uda rams and a template for comparative regional anatomy of the horns of ruminants.

KEY WORDS: Uda rams; Relative horn weight; Horn length.

\section{INTRODUCTION}

The population of sheep in sub-Saharan Africa is estimated at 127 million (Winrock International, 1992) and that of the humid tropics at over 20 million with about $80 \%$ of these in Nigeria (Charray et al., 1992; Gatenby, 2002; Olopade et al., 2005). Uda rams, also known as Northern Nigerian Fulani or Bororo are found in Northern Nigeria, Southern Niger, Central Chad, Northern Cameroon and Western Sudan. They are meat breeds of rams with distinctive markings, the front half of the body is usually black or brown and the back is often white.

A horn is a pointed projection of the skin on the heads of various mammals, consisting of keratin and other proteins surrounding a core of living bone. Animals have a variety of uses for horns, these include: intraspecific display and combat (Lull, 1933; Sampson et al., 1997), defense against predators (Hatcher et al., 1907), thermoregulation and as aids in knocking down vegetation (Farke, 2004). In Nigeria, ram fight is fast becoming a major feature during the Id-el Kabir celebrations, hence its potential as a nascent tourist attraction.

Few studies on the horn of animals have been documented: horn growth in Cantabrian chamois, Rupicapra pyrenaica parva (Pérez-Barbería et al., 1996), horn growth and population quality in Dall sheep (Bunnel, 1978), horn growth in mountain goats, Oreamnos americanus (Côté et al., 1998). However, not much research has been carried out on sheep in Nigeria (Olopade et al.). There is a dearth of information on the morphometry of the horns of domestic animals as anatomical studies on horns are poorly reported. This study aimed at investigating the gross anatomical dimensions of the horn of Uda rams with particular reference to their linear measurements and weights thereby providing baseline data on the subject area. 


\section{MATERIAL AND METHOD}

60 adult Uda were used for this study. They were randomly selected from different slaughter houses within Ibadan Metropolis during ante-mortem and post-mortem meat inspection. The rams were weighed and aged as previously described by Dyce et al. (1996), after being adjudged clinically healthy and without any horn injury.

A total of 10 measurements were carried out on the horns of the rams using metric rules and the mean values of the parameters presented in Table I. The parameters taken are described below:

-Weight of animal (WOA): Obtained using a Microwa Swiss® weighing machine

-Weight of right horn (WORH), weight of left horn (WOLH) and the total weight of both horns (WOBH): These were obtained using a Microwa Swiss ${ }^{\circledR}$ digital weighing balance.

-Relative horn weight (RHW): This was calculated as the percentage of the ratio of WOBH to WOA.

-Right horn length (RHL) and left horn length (LHL): These were measured from the base to hip of the horns.

-Inter-horn distance at base (IHDB) and inter-horn distance at tip of the horns (IDHT): Measured as the distance the left and right horns at the bases and tips respectively.

-Horn base circumference (HBC): Distance round the base of the horn.

Statistical Analysis. All data were subjected to analysis of variance (ANOVA) according to the standard procedure described by Steel \& Torrie (1980). Duncan multiple range test was used to compare means found to be statistically significant $(\mathrm{p}<0.05)$ as described by Obi (1990).

\section{RESULTS}

The mean age of the rams was 3.5 years with a mean body weight of $61 \mathrm{~kg}$ while the relative horn weight was
$0.67 \%$ (Table I). The weights of the right horn (WORH) and left horn (WOLH) were $219.5 \mathrm{~g}$ and $208 \mathrm{~g}$ respectively. There was a significant difference between WORH and WOLH $(\mathrm{p}<0.05)$.

There were strong positive correlations between the weight of animals (WOA) and weight of both horns (WOBH) with a correlation coefficient (r) of 0.91 and between the weight of the animals (WOA) and right horn length (RHL) at a correlation coefficient (r) of 0.84 . The mean values for the length of the right and left horns were $25.6 \mathrm{~cm}$ and $27.4 \mathrm{~cm}$ respectively giving a significant difference $(\mathrm{p}<0.05)$. The mean values for inter-horn distance at base (IHDB), interhorn distance at tip and horn base circumference were $3.8 \mathrm{~cm}$, $61.2 \mathrm{~cm}$ and $17.4 \mathrm{~cm}$ respectively.

Also, there was a strong positive correlation between the weight of the animals (WOA) and the relative horn weight (RHW) with a correlation coefficient of 0.81 . However, a graph of right horn length (RHL) against weight of animal (WOA) gave a slope of $0.4535 \pm 0.0067$ with a significant deviation from zero at $95 \%$ confidence intervals (Fig. 1). This slope value (body weight-horn length index) was then used to establish a relationship between the weight of the animals (WOA) and the length of the right horn (RHL) as:

$$
\text { WOA }(\mathrm{Kg})=\frac{R H L}{0.4535}(\mathrm{~cm})
$$

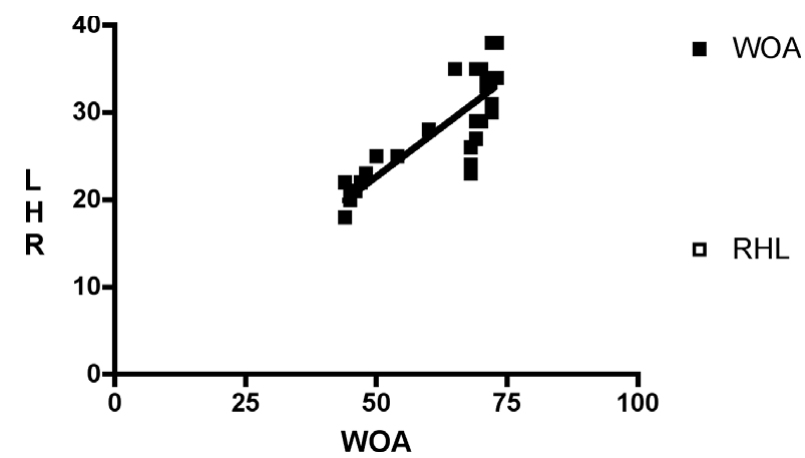

Fig.1. Graph of the relationship between the length of the right horn (RHL) and the weight of animals (WOA).

Table I. Mean values of the dimensions of the horns of Uda rams $(n=60)$.

\begin{tabular}{rccccccccc}
\hline $\begin{array}{c}\text { WOA } \\
(\mathrm{kg})\end{array}$ & $\begin{array}{c}\text { WORH } \\
(\mathrm{g})\end{array}$ & WOLH $(\mathrm{g})$ & $\begin{array}{c}\text { WOBH } \\
(\mathrm{g})\end{array}$ & $\begin{array}{c}\text { RHW } \\
(\%)\end{array}$ & $\begin{array}{c}\text { RHL } \\
(\mathrm{cm})\end{array}$ & $\begin{array}{c}\text { LHL } \\
(\mathrm{cm})\end{array}$ & $\begin{array}{c}\text { IHDB } \\
(\mathrm{cm})\end{array}$ & $\begin{array}{c}\text { IHDT } \\
(\mathrm{cm})\end{array}$ & $\begin{array}{c}\text { HBC } \\
(\mathrm{cm})\end{array}$ \\
\hline $61.2 \pm$ & $219.5 \pm$ & $208.0 \pm 15$. & $424.8 \pm 3$ & $0.67 \pm 0$ & $27.8 \pm 1$ & $29.6 \pm 1$ & $3.77 \pm 0$ & $61.23 \pm 2$. & $17.40 \pm$ \\
2.12 & 15.88 & 71 & 2.03 & .03 & .10 & .13 & .22 & 18 & 0.56 \\
\hline
\end{tabular}

WOA: Weight of animal. WORH: Weight of right horn. WOLH: Weight of left horn. WOBH: Weight of both horns. RHW: Relative horn weight. RHL: Right horn length. LHL: Left horn length. IHDB: Inter-horn distance at base. IHDT: Inter-horn distance at tip. HBC: Horn base circumference. 


\section{DISCUSSION}

The mean body weight of $61 \mathrm{~kg}$ observed in the study indicates that Uda rams are heavier than the West African Dwarf (WAD) rams earlier reported by Olopade et al. The Uda rams are one of the hair sheep breeds of the Sahel type, meat breed with distinctive markings. The heavier weight of these rams could account for their preference as meat animals in comparison to the WAD rams, especially in Nigeria where the Uda rams form the buck of the rams slaughtered during the Ramadan festival. The horns of the rams represented with varying shapes; most of them were twisted laterodorsally, with the horns inclining at almost $180^{\circ}$ angle from the base to the tip. A number of them were twisted giving a sigmoid or almost a U-shape. In all the rams studied, the tips of the horns were usually pointed and hardy while their bases ranged from round to sphere in shape.

The $0.67 \%$ mean relative horn weight obtained in the study is lower than the $15 \%$ relative horn weight reported by Blood et al., 1970, in Rocky Mountain bighorn rams. In bighorn sheep, male reproductive success increases with horn size (Coltman et al., 2002). Horn size determines the outcome of male-male combats that establish social rank (Geist, 1971) and social rank determines priority in access to oestrous ewes only for the largest males (Hogg, 2000). However, artificial selection for slow-growing horns could be compounded by the fact that horn size does not affect the reproductive success of young rams (Coltman et al.).

This study had also shown that the left horns of Uda rams are usually longer than the right with a significant difference $(\mathrm{P}<0.05)$. Nevertheless, the weight of right horn was significantly higher $(\mathrm{P}<0.05)$ than that of the left. The reason for this inverse relationship between the left and right horns in terms of length and weight is not yet established. Also, the strong positive correlation between the weight of the rams and the length of the horns points to the fact that the growth of horns is directly proportional to an increase in body weight in rams. However, Festa-Bianchet et al. (2004), reported that increase in body mass, growth in horn length and circumference in rams were influenced by the availability of nutrient resources.

The strong positive correlation between the weight of rams in this study and the relative horn weight suggests that the biggest ram would have the biggest horn. However, there were a few exceptions where relatively lighter rams presented with bigger and longer horns. This is in conformity with the findings of Festa-Bianchet et al. in bighorn rams. Nevertheless, rams weighing between 60 and $70 \mathrm{~kg}$ presented with bigger and longer horns than those weighing 50 and 60kg. The slope of 0.4535 obtained from the graph of the right horn length (RHL) against the weight of animal (WOA), can be used to estimate the approximate weight of Uda rams. Weight estimation is pivotal to effective drug administration in Veterinary clinical practice. In the absence of a weighing machine, especially in remote areas, the slope obtained in this study would be resortful in estimating the approximate weight of rams. A search for such a relationship between the length of the right horn and the weight of animals in existing literature yielded no result. Hence, the attempt to name it the body weight-horn length (BWHL) index.

There was no correlation between the length of the horns and the inter-horn distance at base (IHDB), which is an anatomical landmark for the interparietal bone of the skull of rams. In all the rams studied, the IHDB was usually small regardless of the weight of the animal or the size of the horns. It is usually marked by a depression wedged between the base of the right and left horns unlike what obtains in the ox where there is an intercornual protuberance in between the left and right horns. The IHDB could be exploited as an important landmark for stunning in Uda rams.

The results obtained in this study will serve as valuable tools in weight estimation in animal management and drug administration in Veterinary clinical practice. The outcome of the morphometric investigations of the horns of these rams also provides a baseline data thereby forming a template for comparative regional anatomy of the horns of ruminants.

\section{ACKNOWLEDGEMENTS}

The author acknowledges the efforts of Balogun Halimah, Tijani Muideen, Akintunde Isiak, Samuel Ekundayo, Arogundade Joshua and Alagbada Muideen in the preliminary aspects of this study.

OLUKOLE, S. G. Investigaciones morfométricas de los cuernos de los carneros Uda en Nigeria: implicancias en la práctica clínica veterinaria. Int. J. Morphol., 28(2):533-536, 2010.

RESUMEN: Se llevaron a cabo estudios morfométricos en los cuernos de 60 carneros Uda. Los valores promedio para el peso relativo de los cuernos y el peso de los cuernos derecho e izquierdo fueron: $0,67 \%, 219,5 \mathrm{~g}$ y $208 \mathrm{~g}$, respectivamente. Los valores medios de las longitudes de los cuernos derecho e izquierdo y la circunferencia de la base del cuerno fueron: $25,6 \mathrm{~cm}, 27,4 \mathrm{~cm}$ y $17,4 \mathrm{~cm}$, respectivamente. Hubo diferencias significativas (p 
$<0,05)$ entre la longitud de los cuernos y entre los pesos de los cuernos derechos e izquierdos. También hubo fuertes correlaciones positivas entre el peso corporal de los animales y la longitud de los cuernos. Un gráfico de la longitud del cuerno derecho contra el peso corporal de los animales con una desviación significativa de cero al $95 \%$ de confiabilidad arrojó un valor pendiente de 0,4535 , que es un índice que se puede utilizar para estimar el peso corporal aproximado de un carnero una vez que la longitud del cuerno derecho se conoce. Este índice, es el primero de su tipo en la literatura. Los resultados obtenidos en este estudio servirán como una herramienta valiosa en la estimación del peso de los animales y en la gestión de la administración del fármaco en la práctica clínica veterinaria. También proporciona una información de referencia sobre los cuernos de los carneros Uda y una plantilla para la anatomía comparativa regional de los cuernos de los rumiantes.

PALABRAS CLAVE: Carneros; Peso relativo de los cuernos; Largo de los cuernos.

\section{REFERENCES}

Blood, D. A.; Flook D. R. \& Wishart, W.D. Weights and growth of Rocky Mountain bighorn sheep in western Alberta. $J$. Wildl. Manage., 34:451-5, 1970.

Bunnell, F. L. Horn growth and population quality in Dall sheep. J. Wildl. Manage., 42:764-75, 1978.

Charray, J.; Humbert, J. M. \& Levif, J. Manual of Sheep Production in the Humid Tropics of Africa. France, CAB International, 1992.

Coltman D. W.; Festa-Bianchet M.; Jorgenson J. T. \& Strobeck C. Age-dependent sexual selection in bighorn rams. Proc. Biol. Sci., 269:165-72, 2002.

Côté, S. D.; Festa-Bianchet, M. \& Smith, K. G. Horn growth in mountain goats (Oreamnos americanus). J. Mammal., 79:406-14, 1998.

Dyce, K. M.; Sack, W. O. \& Wensing C. J. C. Textbook of Veterinary Anatomy. 2. ed. Philadelphia, W. B. Saunders, 1996.

Farke A. A. Horn use in triceratops (dinosauria: ceratopsidae): testing behavioral hypotheses using scale models. Paleoontología Electrónica, 7(1):1-9, 2004.

Festa-Bianchet, M.; Coltman, D. W.; Turelli L.; \& Jorgenson, J. T. Relative allocation to horn and body growth in bighorn rams varies with resource availability. Behavioural Ecology, 15(2):305-12, 2004.
Gatenby, R. M. The Tropical Agriculturist, Sheep. 2. ed. London, Macmillan Publishers Limited, 2002.

Geist, V. Mountain sheep. Chicago, University of Chicago Press, 1971.

Hatcher, J. B.; Marsh, O. C.; \& Lull, R. S. The Ceratopsia. United States Geological Survey Monograph, 49:1-300, 1907.

Hogg J. T. Mating systems and conservation at large spatial scales. In: Vertebrate mating systems Apollonio, M.; FestaBianchet, M. \& Mainardi, D. (eds.). Singapore, World Scientific, 2000. pp. 214-52.

Lull, R. S. A revision of the Ceratopsia, or horned dinosaurs. Memoirs of the Peabody Museum of Natural History, 3:1$175,1933$.

Obi. I. U. Statistical Methods of Detecting Differences Between Treatment Means. $2^{\text {nd }}$ ed. Enugu, Nigeria, Snap. Press, 1990. pp. 24-35.

Olopade, J. O.; Onwuka, S. K.; Balogun, B. A.; \& Oke, B. O. Morphometric investigation of the brain of West African Dwarf Sheep in Nigeria. Int. J. Morphol., 23(2):99-104, 2005.

Pérez-Barbería F. J.; Robles L., \& Nores C. Horn growth pattern in Cantabrian chamois Rupicapra pyrenaica parva: influence of sex, location and phaenology. Acta Theriol., 41:83-92, 1996.

Sampson, S. D.; Ryan, M. J., \& Tanke, D. H. Craniofacial ontogeny in centrosaurine dinosaurs (Ornithischia: Ceratopsidae): taxonomic and behavioural implications. Zool. J. Linn. Soc., 121:293-337, 1997.

Steel, R. G. D. \& Torrie, J. H. Principles and Procedures of Statistics. 2. ed. New York, McGraw Hill, 1980.

Winrock International. Assessment of Animal Agriculture in SubSahara Africa. Morrilton, Arkanses U.S.A, WIIAD, 1992.

\author{
Correspondence to: \\ Dr. S. G. Olukole \\ Department of Veterinary Anatomy \\ Faculty of Veterinary Medicine \\ University of Ibadan \\ NIGERIA
}

Email: deborolukole@yahoo.com

Received: 26-01-2009

Accepted: 21-07-2009 